\title{
Z RUDOMINA DO SHUNTEHFU. ŻYCIE MISYJNE WE WSPOMNIENIACH KS. FRANCISZKA ARCISZEWSKIEGO CM (1910-2006) - PRZYCZYNEK DO DZIEJÓW PREFEKTURY APOSTOLSKIEJ ZGROMADZENIA MISJI W PÓŁNOCNYCH CHINACH
}

Zgromadzenie Misji, wspólnota zrzeszająca księży katolickich, powstało we Francji w roku 1625. Do głównych charyzmatów zgromadzenia należały: tzw. misje ludowe, czyli chrystianizacja ubogiej, często zamieszkującej peryferia, ludności, kształcenie w seminariach przyszłych duchownych oraz branie czynnego udziału w ewangelizacji ludów Afryki, obu Ameryk i Azji ${ }^{1}$. Proponowany przez misjonarzy styl pracy duszpasterskiej zyskał bardzo szybko uznanie duchowieństwa spoza Francji, dlatego w struktury wspólnoty dość szybko zaczęli wstępować Włosi, Szkoci i Niemcy ${ }^{2}$. Już za życia założyciela zgromadzenia, św. Wincentego a Paulo (1581-1660), pierwsi misjonarze dotarli na Madagaskar ${ }^{3}$. Księża pracowali również w północnej Afryce oraz na Bliskim i Dalekim Wschodzie .

Do Zgromadzenia Misji od poł. wieku XVII wstępowali również Polacy. Wiek XX przyniósł natomiast wśród polskich księży wzrost powołań zwłaszcza do służby $\mathrm{w}$ dalekich krajach. Polscy księża $\mathrm{z}$ tego

\footnotetext{
${ }^{1}$ Misjonarze św. Wincentego a Paulo $w$ Polsce (1651-2001), t. I: Dzieje, red. S. R o s p o n d, Kraków 2001, s. 17-18.

2 Tamże, s. 18.

${ }^{3}$ Krótka wiadomość o duchu i celach Zgromadzenia XX. Misjonarzy, „Roczniki Obydwu Zgromadzeń św. Wincentego a Paulo" [dalej: ROZ], R. 35, 1932, nr 1, s. 6-7.

${ }^{4}$ L. M e z z a d ri, F. On n i s, Historia Zgromadzenia Misji, t. II/1: Zgromadzenie Misji w XVIII w.: Francja, Włochy, Misje (1697-1788), tłum. W. B o m b a, Kraków 2002, s. 482-527.
}

„Nasza Przeszłość” t. 132: 2019, s. 397-420. 
zgromadzenia dotarli m.in. do Australii, puszczy amazońskiej oraz Chin. W latach 1929-1949 w północnych Chinach, w mieście Shuntehfu istniała misja, a następnie prefektura apostolska, całkowicie obsadzona przez wysłanników polskiej prowincji Zgromadzenia Misji. Ich dzieje, pomimo licznie ocalałych materiałów źródłowych, wciąż nie zostały dokładnie opracowane. Podobnie przedstawia się sytuacja z biografiami księży działających na terenie Azji. W materiałach, które ukazały się drukiem dostępne są tylko krótkie ogólne noty biograficzne lub listy misjonarzy.

Podstawowymi publikacjami na temat Zgromadzenia Misji pozostają: Historia Zgromadzenia Misji autorstwa Luiggiego Mezzadri ${ }^{5}$ oraz Misjonarze św. Wincentego a Paulo w Polsce, tom I: Dzieje oraz tom II: Biografie, pod redakcją Stanisława Rosponda i Jana Dukały ${ }^{6}$. Książką, bezpośrednio odnoszącą się i opisującą wydarzenia w misji Shuntehfu, jest Sylwetka duchowa księdza doktora Wackawa Szuniewicza opracowana przez Franciszka Stawarskiego ${ }^{7}$. Zawiera ona listy lekarza opisujące jego pracę w północnych Chinach. Dodatkowym

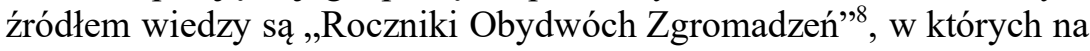
bieżąco publikowano, w latach 30. i 40. XX w., obszerne relacje kapłanów z Azji. Zachowała się także korespondencja i wspomnienia uczestników misji m.in. Wojciecha Sojki i Franciszka Arciszewskiego, które do tej pory nie doczekały się publikacji. Dokumenty te przechowywane są obecnie w Archiwum Polskiej Prowincji Zgromadzenia Księży Misjonarzy na Stradomiu w Krakowie.

Spuścizna tylko po księdzu Arciszewskim liczy dwadzieścia jeden teczek $(0,5$ m.b.), o roboczych sygnaturach II/1 oraz II/2. Zawierają one przede wszystkim dokumenty osobiste Franciszka Arciszewskiego, m.in. ankietę osobową, życiorysy, dokumentację medyczną. Osobny dział zajmują wspomnienia księdza z posługi w Chinach, fotografie, kazania oraz korespondencja w językach: polskim, angielskim i chińskim. Dzięki tym materiałom w większości można odtworzyć przebieg jego posługi kapłańskiej, ze szczególnym uwzględnieniem pobytu w Chinach (1935-1949).

\footnotetext{
${ }^{5}$ L. M e z z a d r i, F. O n n i s, dz. cyt.

${ }^{6}$ Misjonarze, t. I, dz. cyt.; Misjonarze św. Wincentego a Paulo w Polsce (1651-2001),

t. II-1: Biografie, red. J. D u k a ł a CM, Kraków 2001.

${ }^{7}$ Sylwetka duchowa księdza doktora Wactawa Szuniewicza, oprac. F. S t a w a r s ki, Brasil 1977.

8 „Roczniki Obydwu Zgromadzeń św. Wincentego a Paulo”.
} 
Celem niniejszego artykułu jest przede wszystkim przedstawienie sylwetki jednego z misjonarzy - księdza Franciszka Arciszewskiego (1910-2006) - którego lata posługi w Chinach przypadły na niespokojny okres wojny Chin z Japonią oraz walk wewnętrznych między wojskami Czang-Kaj-Szeka i bojownikami Mao Zedonga. Ks. Arciszewski pozostawił po sobie niepublikowane wspomnienia $\mathrm{z}$ okresu misji w Chinach oraz późniejszych placówek, które stanowią unikatowy zapis historii ostatecznego zlikwidowania polskiej prefektury w Chinach i zamknięcia się kraju na obce wpływy. Sama działalność polskiej misji i prefektury również zasługuje na całościowe i dokładne opracowanie, którego wciąż brakuje.

Ewangelizacja prowadzona przez Zgromadzenie Misji na terenach chińskich rozpoczęła się $\mathrm{w}$ roku 1698 , kiedy to $\mathrm{z}$ misją do Pekinu został wysłany włoski ks. Ludwik Antoni Appiani. Mieszkańcy Cesarstwa Chińskiego wyznawali tradycyjny system religijny oparty na naukach Konfucjusza, a ich stosunek do nowych wyznań cechowała nieufność ${ }^{9}$. Dodatkowo duchowni katoliccy przebywający w Chinach musieli podporządkować się woli Rzymu, pomimo niezadowolenia cesarzy uznających księży za swoich poddanych. Narastający na tym tle konflikt doprowadził do pierwszych prześladowań oraz deportacji. Ludwik Appiani został aresztowany w listopadzie roku $1706^{10}$. W różnych więzieniach spędził kolejne dwadzieścia dziewięć lat, a zwolniony został dopiero na krótko przed swoją śmierciąa ${ }^{11}$. Ostatecznie, po sześćdziesięciu dziewięciu latach pracy duszpasterskiej w Chinach, kiedy w roku 1767 umarł ostatni z miejscowych księży misjonarzy, a kolejni z Europy nie zostali wpuszczeni na terytorium kraju, nastąpiło przejściowe przerwanie działalności Zgromadzenia Misji w Cesarstwie Chińskim ${ }^{12}$.

W roku 1786 do Pekinu przybyła pierwsza grupa kontynuatorów dzieła św. Wincentego a Paulo ${ }^{13}$. Przewodził im ks. Mikołaj Raux, który zasłynął na cesarskim dworze jako astronom ${ }^{14}$. Poparcie jakie misjonarze otrzymali od samego cesarza pozwoliło im odnowić zniszczone kościoły

\footnotetext{
${ }^{9}$ L. M e z z a dri, F. O n n i s, dz. cyt., s. 403.

10 Tamże, s. 409.

${ }^{11}$ K. B r o d a, Zgromadzenie Księży Misjonarzy w Chinach, cz. 1 (szkic historyczny), „Meteor”, R. 23, 1931, nr 5, s. 118.

${ }^{12}$ L. M e z z a d r i, F. O n n i s, dz. cyt., s. 424- 426.

13 Tamże, s. 437.

${ }^{14}$ K. B r o d a, Zgromadzenie Księży Misjonarzy, cz. 1, dz. cyt., s. 119.
} 
i rozpocząć ewangelizację miejscowej ludności ${ }^{15}$. Było to jednak tylko przejściowe ocieplenie stosunków między katolikami a władzą w Pekinie. Na początku wieku XIX doszło do nasilenia represji. Wielu księży zostało zamordowanych, a innych zmuszono do wyjazdu z Chin ${ }^{16}$. Prześladowania zakończyły się dopiero w latach 40. wieku XIX, by wybuchnąć na nowo w czasie powstania bokserów w latach 1899-1901 ${ }^{17}$.

Od roku 1912 utworzono świeckie państwo chińskie, w którym nie prześladowano już oficjalnie katolicyzmu. Zapanowała całkowita swoboda religijnych praktyk, ale osłabionym krajem nieustannie wstrząsały niepokoje społeczne i wojny domowe ${ }^{18}$.

W latach 20. wieku XX zapadła decyzja, aby do Chin przybyli misjonarze nie tylko z krajów tzw. kolonialnych, ale również innych. Takim kapłanom znacznie łatwiej było zdobyć zaufanie miejscowej ludności, gdyż nie kojarzono ich z wyzyskiem i grabieżami ${ }^{19}$. Wśród tej grupy znaleźli się Polacy.

Pierwsza grupa polskich kapłanów wyruszyła z Krakowa w roku $1929^{20}$. Ówczesny wizytator ks. Józef Kryska był wielkim orędownikiem misyjnego charyzmatu zgromadzenia ${ }^{21}$ i to dzięki jego staraniom udało się zorganizować wyprawę do Chin. Grupa składała się z księdza Ignacego Krauze - późniejszego superiora i biskupa, doświadczonego misjonarza, który pracował wcześniej w Brazylii, oraz księdza Antoniego Górskiego $^{22}$. Pomocą i wsparciem mieli im służyć trzej klerycy, którzy zostali wyświęceni już na nowej placówce ${ }^{23}$. Byli to Wacław Czapla, Stanisław Kotliński oraz Franciszek Stawarski ${ }^{24}$. Towarzyszył im rów-

\footnotetext{
${ }^{15}$ L. M e z z a d r i, F. O n n i s, dz. cyt., s. 439-450.

${ }^{16}$ K. B r o d a, Zgromadzenie Księży Misjonarzy, cz. 1, dz. cyt., s. 120.

17 S. R o s p o nd, Polscy Misjonarze św. Wincentego a Paulo w Chinach (1929-1949), http://famvin.org/Wiki-pl/Polscy_Misjonarze_\%C5\%9Bw._Wincentego_a_Paulo_w_Chi nach_\%281929_-_1949\%29, []̄ostęp dnia 09.05.15].

${ }^{18}$ K. B r o d a, Zgromadzenie Księży Misjonarzy, cz. 1, dz. cyt., s. 121.

${ }^{19}$ S. R o s p o n d, Polscy Misjonarze, dz. cyt.

${ }^{20} \mathrm{~K}$. B ro d a, Zgromadzenie Księży Misjonarzy w Chinach, cz. 2: Pod sztandarem krzyża, „Meteor”, R.23, 1931, nr 5, s. 123-125.

21 S. F e ndzin, Wrażenia z podróży I. grupy misyjnej XX. Misjonarzy do Chin w roku 1929, ROZ, R. 34, 1931, nr 2, s. 165-170.

22 S. R o s p o nd, Biogramy polskich misjonarzy pracujacych $w$ Chinach $w$ latach 1929-1949, http://famvin.org/wiki-pl/Biogramy_polskich_misjonarzy_pracuj\%C4\% 85cych_w_Chinach_w_latach_1929-1949, [dostęp dnia 09.05.15].

${ }^{23}$ Misjonarze, t. II-1, dz. cyt., s. 117-120.

${ }^{24} \mathrm{~S}$. R o s p o n d, Biogramy polskich misjonarzy, dz. cyt.
} 
nież brat Stanisław Fedzin, który w roku 1929 miał pięćdziesiąt sześć lat i postrzegany był jako osoba w zaawansowanym wieku ${ }^{25}$.

Polscy kapłani szybko zorientowali się, że na miejscu mają do dyspozycji bardzo małe środki, w porównaniu do wydatków jakie ich czekają $^{26}$. Misję ulokowano kilkaset kilometrów na południowy zachód od stolicy państwa - Pekinu, w mieście Shuntehfu znajdującym się $\mathrm{w}$ prowincji Hopeh ${ }^{27}$. Zamieszkiwało ją nieco ponad milion mieszkańców, trudniących się uprawą niewielkich pól ryżowych oraz hodowlą bydła. Teren ten zajmowali głównie wyznawcy konfucjanizmu, a liczbę katolików księża misjonarze szacowali na około szesnaście tysięcy, przy czym byli oni bardzo rozproszeni we wszystkich dziewięciu rozległych powiatach prowincji ${ }^{28}$.

W końcu lat 20. wieku XX w prowincji Hopeh funkcjonowało jedynie sześć niewielkich kościołów parafialnych oraz sto pięćdziesiąt sześć kaplic domowych ${ }^{29}$.

Energiczne działania członków pierwszej grupy misyjnej spowodowały, że placówka misyjna w Shuntehfu została w roku 1933 podniesiona do rangi prefektury apostolskiej przez papieża Piusa XI (19221939). Na jej czele stanął ks. Ignacy Krauze ${ }^{30}$.

Polscy księża misjonarze w roku 1932 objęli swoim zarządem jeszcze jedno chińskie miasto - położony na południe od Szanghaju port Wenchow $^{31}$. Utworzoną tam misją katolicką kierował ks. Paweł Kurtyka, a podlegali mu wysłannicy Polskiej Prowincji Zgromadzenia Misji ${ }^{32}$.

Przez prawie dwadzieścia lat księża misjonarze z Polski nieprzerwanie żyli i pracowali w Chinach. W tym czasie przybyło dziewięć grup misyjnych składających się łącznie z czterdziestu księży, braci oraz kleryków. Już w rok po pierwszych misjonarzach do prowincji Hopeh dotarli: brat Stanisław Fasula, kleryk Jan Redzimski oraz dwóch

\footnotetext{
${ }^{25}$ Tamże.

${ }^{26}$ W. J ę c z m i o n k a, Prefektura Apostolska Shuntehfu Chiny 1935, cz. 1, http://adgen tes.misjonarze.org/wp-content/uploads/2009/10/Chiny-Jeczmionka-czl-final.pdf, [dostęp dnia 09.05.15], s. 1-2.

27 Tamże, s. 2; Spolszczone nazwy miejscowe oraz nomenklaturę administracyjną przyjęto za S. R o s p o n d, Polscy Misjonarze, dz. cyt.; chiń. prowincja Hebei (przyp. aut.).

28 Tamże.

29 Tamże.

${ }^{30}$ W. J ę c z m i o n k a, Prefektura Apostolska Shuntehfu Chiny 1935, cz. 1, dz. cyt., s. 2.

${ }^{31}$ Wen Zhou w prowincji Yuhuan (przyp. aut.)

${ }^{32}$ W. J ę c z m i o n k a, Prefektura Apostolska Shuntehfu Chiny 1935, cz. 1, dz. cyt., s. 2.
} 
księży: Marcin Cymbrowski i lekarz Wacław Szuniewicz ${ }^{33}$. Ten ostatni bardzo szybko zasłynął wśród Chińczyków swoim wykształceniem okulistycznym i ogólnomedycznym ${ }^{34}$. Wraz $\mathrm{z}$ towarzyszącymi mu księżmi: Konradem Trzeciakiem, który zajmował się farmacją oraz Marcinem Cymbrowskim - stomatologiem, doprowadzili do powstania szpitala w Shuntehfu ${ }^{35}$. Placówka ta posiadała swoje filialne gabinety lekarskie w okolicznych parafiach. Każdy potrzebujący, niezależnie od wyznania, znajdował w nich bezpłatną pomoc medyczną ${ }^{36}$. Ks. Szuniewicz i jego zespół pracowali nadal nawet w czasie swojej ucieczki z prowincji Hopeh, gdy w roku 1946 komunistyczne władze zlikwidowały zagraniczne misje ${ }^{37}$.

W roku 1932 do Azji trafili księża Paweł Kurtyka, Józef Grzeliński, Wilhelm Ciemała oraz dwóch braci Stanisława Cieplak i Władysław Prinz $^{38}$. W roku następnym dotarli kolejni księża: Wiktor Brzózka, Kazimierz Całka, Władysław Giemza, Wawrzyniec Karcz, Łukasz Sitko oraz Józef Woźniacki ${ }^{39}$. W roku 1936 dotarli następni misjonarze z Polski, czyli Jan Jankowski, Gothard Krzysteczko, Franciszek Bąba (Brożek), Feliks Stefanowicz i Ignacy Wieczorek. W roku 1937 posługę w Chinach podjął ks. Henryk Sawicki. W roku 1939 do prowincji Hopeh przybyli księża Wojciech Sojka, Konrad Trzeciak oraz Władysław Serzysko $^{40}$. Jako ostatni, już po drugiej wojnie światowej w roku 1947, przyjechali księża Wilhelm Golli oraz Antoni Czapla ${ }^{41}$.

Największa grupa misyjna przybyła do Chin w roku 1935. W znacznej mierze dzięki pracy ośmiu nowych kapłanów stało się możliwe rozszerzenie zasięgu misji oraz usystematyzowanie działalności wiejskich parafii. W jej skład wchodzili księża Franciszek Krzyżak, Kazimierz Skowyra, Wacław Jęczmionka, Stanisław Czerwiński, Konstanty

\footnotetext{
${ }^{33}$ S. R o s p o n d, Biogramy polskich misjonarzy, dz. cyt.

${ }^{34}$ Sylwetka duchowa, dz. cyt., s. 4-9.

${ }^{35}$ S. R o s p o n d, Polscy Misjonarze, dz. cyt.

36 J. W i e l a w s k i, Polska Misja katolicka $w$ Chinach, ROZ, R. 37, 1934, nr 4, s. $377-$ 379.

${ }^{37}$ Sylwetka duchowa, dz. cyt., s. 120-126.

${ }^{38} \mathrm{~S}$. R o s p o n d, Biogramy polskich misjonarzy, dz. cyt.

39 Tamże.

40 Tamże.

${ }^{41}$ Misjonarze, t. II-1, dz. cyt., s. 115-116.
} 
Witaszek, Józef Grabka i Józef Paciorek ${ }^{42}$. W tej grupie przybył do Chin również ks. Franciszek Arciszewski.

Franciszek Arciszewski urodził się 24 stycznia 1910 roku w Petersburgu $^{43}$ jako trzecie dziecko Stanisława oraz Emilii z domu Maciesowicz. Jego rodzice pochodzili z Wileńszczyzny, ale z Petersburgiem związani byli przez pracę. Franciszek miał dwie starsze siostry: Zofię i Julię, oraz dwie młodsze: Józefę i Reginę ${ }^{44}$.

W roku 1917 przyszły misjonarz rozpoczął naukę w szkole polskiej w Petersburgu i kontynuował ją tam przez dwa lata ${ }^{45}$. Koniec pierwszej wojny światowej i upadek caratu w Rosji spowodował anarchię i bezprawie. Stanisław Arciszewski postanowił nie narażać swojej rodziny i powrócił do rodzinnej wsi Rudomino. W roku 1919 Arciszewscy dotarli na Wileńszczyznę. Ks. Franciszek tak opisuje ten okres w swoim życiorysie: „Jakoż dnia 16 maja 1919 roku opuściliśmy Petersburg, by po prawie trzy miesiące trwającej podróży, zostawiwszy poza sobą front bolszewicko-polski stanąć w rodzinnej wiosce ojca zwanej Rudomino, położonej o 12 kilometrów na południe od Wilna"46.

Edukację przyszłego księdza przerywały konflikty zbrojne, najpierw pomiędzy bolszewicką Rosją a Polską w 1920, a następnie walki z Litwinami o Wilno w październiku tego samego roku. 27 maja 1920 roku Franciszek Arciszewski przystąpił po raz pierwszy do spowiedzi, a dzień później do komunii świętej, co było dla niego wielkim przeżyciem. Swoją edukację w szkole powszechnej zakończył pomyślnie $\mathrm{w}$ roku 1922. Nie wspominał jednak tego faktu $\mathrm{z}$ entuzjazmem: „W roku 1922 złożyłem pomyślnie egzamin do klasy pierwszej gimnazjum ojców jezuitów w Wilnie. Ale $\mathrm{z}$ braku środków do zakładu nie poszedłem. Uczęszczałem dalej do szkoły w Rudominie, powtarzając przebrany już materiał" 47 .

\footnotetext{
${ }^{42}$ Misjonarze, t. II-1, dz. cyt., s. 115-116.

43 Archiwum Polskiej Prowincji Zgromadzenia Księży Misjonarzy (dalej: AMS), Akta Personalne ks. Franciszka Arciszewskiego [dalej: AP Arciszewskiego], sygn. I/1, Kwestionariusz przyjęcia kleryka do Zgromadzenia [b.d.].

44 AMS, AP Arciszewskiego, sygn. I/1, Kwestionariusz osobowy dla cudzoziemców składających podanie o zezwolenie na pobyt stały w Polskiej Rzeczypospolitej Ludowej z roku 1985.

45 AMS, AP Arciszewskiego, sygn. I/1, Życiorys z roku 1934.

46 Tamże.

${ }^{47}$ AMS, AP Arciszewskiego, sygn. I/1, Życiorys z roku 1934.
} 
Dopiero w roku 1924 rozpoczął edukację w szkole średniej. Początkowo planował naukę w salezjańskim gimnazjum w Różanym Stoku pod Grodnem. Była to jednak odległa placówka wymagająca sporych nakładów finansowych związanych $\mathrm{z}$ zakwaterowaniem i podróżami do domu. Franciszek Arciszewski ostatecznie zdecydował się wybrać Małe Seminarium Księży Misjonarzy w Wilnie, które właśnie otwarto. Został przyjęty do klasy drugiej i rozpoczął edukację. To właśnie w czasie kształcenia w Wilnie postanowił wstapić do Zgromadzenia Misji. W tym celu udał się do Krakowa, by zapisać się do misjonarskiego Seminarium Internum na Kleparzu, w którym 27 listopada 1927 roku zaczął naukę i kontynuował ją przez trzy lata. Dnia 8 grudnia 1929 roku złożył śluby zakonne ${ }^{48}$.

W wieku dwudziestu jeden lat Arciszewski zdał maturę i jeszcze w tym samym roku 1931, rozpoczął studia filozoficzno-teologiczne

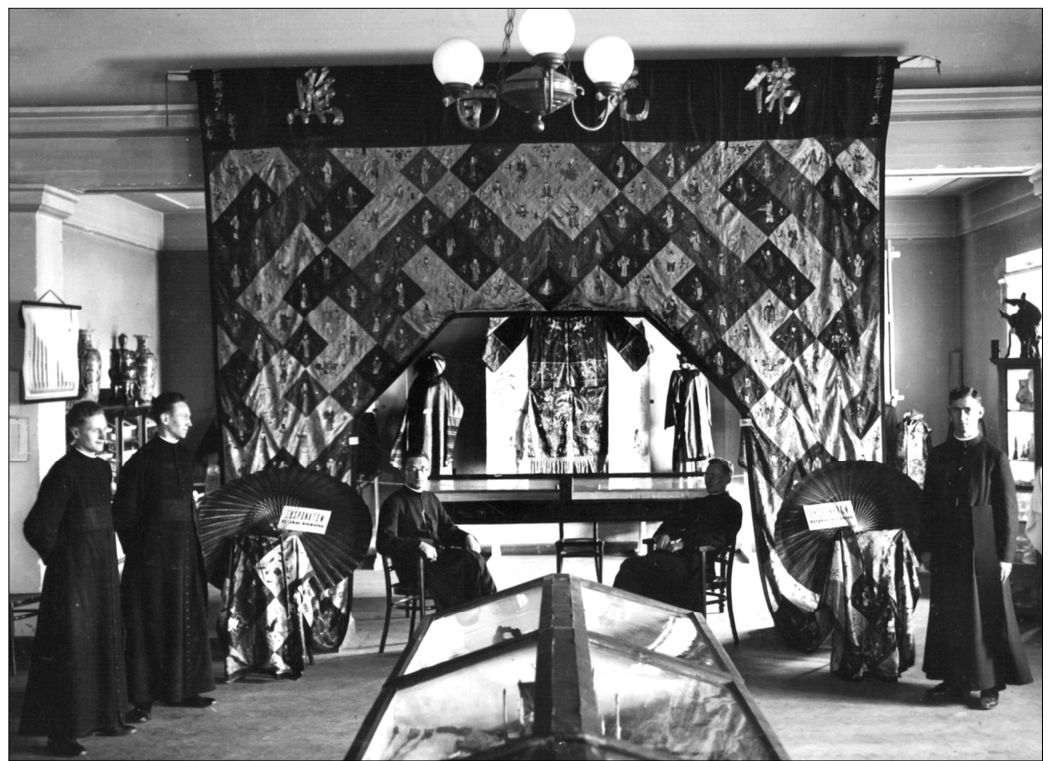

Wystawa misyjna - organizatorzy klerycy F. Arciszewski i A. Schletz

48 Tamże. 
w Instytucie Teologicznym Księży Misjonarzy znajdującym się na krakowskim Stradomiu ${ }^{49}$. Po czterech latach, 27 stycznia 1935 roku w Krakowie, Franciszek Arciszewski przyjął świecenia kapłańskie z rąk biskupa Stanisława Rosponda, kończąc tym samym okres swojej edukacji ${ }^{50}$.

Po przyjęciu święceń zgłosił swoim przełożonym chęć opuszczenia Polski i udania się na misje zagraniczne. Zgromadzenie Misji miało wówczas swoje placówki w chińskiej prowincji Hopeh, w których brakowało duchownych, dlatego właśnie tam został skierowany młody misjonarz. W towarzystwie księdza Stanisława Czerwińskiego i księdza Józefa Grabka, Franciszek Arciszewski opuścił Kraków 3 maja 1935 $\mathrm{roku}^{51}$. Duchowni udali się do Rzymu, a następnie do portu w Trieście, z którego 10 maja wyruszyli w dalszą podróż do Azji. Po kilkutygodniowej podróży statkiem do Szanghaju misjonarze zmienili środek transportu. Do Shuntehfu dotarli pociągami po trzech dniach ${ }^{52}$.

$\mathrm{Na}$ miejscu ks. Franciszek Arciszewski otrzymał chińskie dane personalne, którymi posługiwał się w kontaktach $\mathrm{z}$ miejscowymi. Odtąd nazywał się Wen Dży Pin. Następnie przeszedł intensywny, dziesięciomiesięczny kurs języka chińskiego oraz zapoznał się z miejscowymi zwyczajami i praktykami ${ }^{53}$. Kolejnym etapem duszpasterskiej służby księdza Arciszewskiego było objęcie posługi w miejscowości Czang-ku-dżaj, gdzie został mianowany katechetą ${ }^{54}$. Po latach wspominał, że odprawiano tam msze św. w języku łacińskim, co było dla niego wybawieniem, ponieważ nie znał jeszcze dobrze chińskiego. Młody misjonarz zachwycił się tamtejszą tradycją wspólnej porannej i wieczornej modlitwy w kościele. Do jego obowiązków należało odprawianie mszy św. oraz sprawowanie sakramentów. Zwłaszcza podczas tych ostatnich miał okazję zapoznać się bliżej z miejscową ludnością, z którą z czasem się zaprzyjaźnił ${ }^{55}$.

Praca ewangelizacyjna w Chinach była niezwykle wymagająca dla polskich księży. Składało się na to wiele czynników związanych

\footnotetext{
49 Tamże.

${ }^{50}$ AMS, AP Arciszewskiego, sygn. I/1, Życiorys z roku 1967.

${ }^{51}$ S. R o s p o n d, Polscy Misjonarze św., dz. cyt.

${ }^{52}$ F. A r c i s z e w s k i, Wspomnienia z Chin, mps, Warszawa 1990, s. 1.

${ }^{53}$ F. A r c is z e w s k i, dz. cyt., s. 2-5.

54 Tamże, s. 5.

55 W. J ę c z m i o n k a, Prefektura Apostolska Shuntehfu Chiny 1935, cz. 1, dz. cyt., s. 4; por. F. Arcis ze w s ki, dz. cyt., s. 3.
} 
zarówno z aklimatyzacją oraz komunikacją, jak i specyficzną sytuacją geopolityczną w regionie. Misjonarze wielokrotnie w swoich listach do kraju, wspominają trudności z nauką języka. Największym problemem w kontaktach międzyludzkich był fakt, iż tamtejszy dialekt języka chińskiego ulegał zmianom i modyfikacjom językowym tak często, że misjonarze uczyli się go zazwyczaj tylko poprzez obcowanie z mieszkańcami swojej parafii ${ }^{56}$. Dodatkową bolączką polskich duchownych okazała się specyficzna lokalna kuchnia, która zawierała niezwykle dużo ryżu i przypraw powodujących u przyjezdnych choroby układu pokarmowego. Innym utrudnieniem dla misjonarzy były duże przestrzenie oraz zróżnicowanie kraju. Odległości między parafiami a prefekturą apostolską w Shuntehfu liczyły niejednokrotnie kilkadziesiąt kilometrów. W tym czasie drogi znajdowały się w opłakanym stanie lub nie istniały w ogóle. $\mathrm{Z}$ tym wyzwaniem duchowni poradzili sobie, zaopatrując się w rowery, przystosowane do jazdy zarówno w terenie nizinnym, jak i górskim ${ }^{57}$.

Najgroźniejsza okazała się być jednak niestabilna sytuacja polityczna panująca $\mathrm{w}$ dawnym chińskim imperium. Od momentu oficjalnego końca cesarstwa w roku 1912 państwo znajdowało się w stanie permanentnej anarchii i wojny domowej. Lokalni gubernatorowie i generałowie dysponujący prywatnymi armiami, toczyli wojny zarówno między sobą, jak i z rządem centralnym. Sytuacje komplikowało dodatkowo istnienie półjawnych i tajnych stowarzyszeń oraz bojówek chińskich, których przewodnim założeniem była walka z obecnością obcych i ich wpływami w Chinach. Tym samym wrogami zostali również wyznawcy chrześcijaństwa i sami misjonarze. O swoim spotkaniu z taką właśnie grupą wspomina w listach ks. Franciszek Arciszewski: „,bandy zbrojnych «łupieżców» napadały na wyznaczone wioski katolików, rabując ich mienie, a ludzi wypędzają ${ }^{58}$. Uciekinierzy przybywali do swych krewnych lub innych katolickich wiosek, powodując ich przeludnienie, co w ubogim górzystym terenie prowincji Hopeh było niezwykle nie-

\footnotetext{
${ }^{56}$ F. K r z y ża k, In Nomine Domini. Nie nam lecz Imieniowi Twojemu Panie daj chwałe, cz. 1, http://adgentes.misjonarze.pl/wp-content/uploads/2009/10/Chiny-Krzyzakcz1-final.pdf, [dostęp dnia 9.05.2015], s. 7-8; por. F. A r c i s z e w s k i, dz. cyt., s. 4-5.

${ }^{57}$ W. S o j k a, Koniec misji $w$ Chinach, mps, b.m. 1986, s. 5.

58 List X. Franciszka Stawarskiego do X. W. Jęczmionki w Chetmnie, ROZ, R. 35, 1932, nr 1, s. 35-44.
} 
bezpieczne i łatwo mogło doprowadzić do klęski głodu. Bardzo częste napady dotykały również podróżnych"59.

W latach 30. wieku XX sytuacja polityczna uległa pogorszeniu. Nacjonalistyczny rząd Czang Kaj-szeka wprowadził liczne reformy administracyjne oraz polityczne. Lokalni urzędnicy przyzwyczajeni do roli „udzielnych władców” inspirowali i wywoływali liczne powstania i rebelie ${ }^{60}$.

W roku 1931 doszło w północnych Chinach do wojny domowej. Rywalizujący ze sobą lokalni generałowie rozpoczęli konflikt zbrojny, w który wciągnięto armię rządową. Miasto Shuntehfu zostało oblężone. Nieliczny, zaledwie tysięczny garnizon, bronił murów przez wiele tygodni pomimo stałych bombardowań i ostrzału z dział ${ }^{61}$. Ostatecznie na początku sierpnia doszło do szturmu generalnego. Budynki misji, jak podawali w swoich listach księża misjonarze, znajdowały się tuż przy murach miejskich, a w szpitalu prowadzonym przez doktora Szuniewicza przebywało wielu rannych obrońców ${ }^{62}$. Nie zważając no to, wojska rządowe wtargnęły również do misji, dokonując ogromnych spustoszeń. Księża Szuniewicz i Górski, którzy w momencie szturmu byli w Shuntehfu, opisywali ogrom zniszczeń w wyniku walk i grabieży, która nastąpiła później. Szczęśliwym zbiegiem okoliczności nikt nie został zabity, a szpital misyjny nie został splądrowany, tak więc szybko mógł wznowić swoją działalność ${ }^{63}$.

Tragiczne wydarzenia opisał ks. Szuniewicz w swoim liście do Zgromadzenia Misji w Polsce: „Najcięższy dzień, był 6 sierpnia. Ciężkie pociski zrobiły wyłom w murze miejskim w pobliżu Polskiej Misji. Z hukiem bomb zrzucanych z krążących nad miastem samolotów, wojska rządowe wtargnęły do miasta. Wściekli z powodu poniesionych strat i niezwykle zaciętego, jak na Chiny, oporu, rzucili się zapamiętale

\footnotetext{
${ }^{59}$ F. A r c i s z e w s k i, dz. cyt., s. 20-24.

${ }^{60}$ Czang Kaj-szek był przywódcą Kuomintangu po śmierci jej założyciela Sun Jatsena w roku 1925. Od roku 1928 stał się faktycznym przywódcą Republiki Chińskiej. W roku 1934 udało mu się stłumić powstanie komunistów, dowodzonych przez Mao Zedonga. W czasie II wojny światowej nacjonaliści zawarli sojusz taktyczny z ,,czerwonymi”, aby wyprzeć Japończyków z Chin (przyp. aut.).

${ }^{61}$ Sylwetka duchowa, dz. cyt., s. 59-63.

${ }^{62}$ List X. Dr. Wactawa Szuniewicza do jednej z Sióstr Miłosierdzia, ROZ, R. 35, 1932, nr 1, s. 29-30.

${ }^{63}$ Tamże.
} 
na pobliskie domy, domy misji. Przez parę minut strzelano do bram i okien. Jednocześnie $\mathrm{z}$ murów miejskich, obsypano misje gęstym gradem kul z karabinów maszynowych. Kule przeszyły szyby okien, utkwiły w podłodze, w ścianach pokojów księży przedziurawiły stoły i szafy... Łaska Boża zachowała personel. Jedna tylko odźwierna z zakładu Sióstr Miłosierdzia, została ciężko ranna, kula zdruzgotała jej nogę i przeszyła klatkę piersiową"64.

Po tych wydarzeniach w prowincji Hopeh zapanował względny spokój trwający sześć lat.

W roku 1937 doszło do konfliktu japońsko-chińskiego. Armie cesarstwa, znacznie mniej liczne, ale lepiej wyszkolone i wyekwipowane, szybko rozprawiły się z obrońcami. Japończycy dopuszczali się okrutnych zbrodni na ludności cywilnej, uważając Chińczyków za ludzi gorszej kategorii. Mimo to żołnierze japońscy niejednokrotnie życzliwie odnosili się do zagranicznych misjonarzy ${ }^{65}$. W czasie okupacji japońskiej trwającej do roku 1945, kiedy to wojska cesarza skapitulowały przed aliantami i wycofały się z Chin, polscy księża odnotowali jeden przypadek, kiedy to, w wyniku niesubordynacji, żołnierze japońscy $\mathrm{w}$ czasie zdobywania miasta Chengtingfu zamordowali zagranicznego duchownego ${ }^{66}$.

Ocena żołnierzy japońskich przez księdza Franciszka Arciszewskiego była niejednoznaczna: bulwersowało go okrucieństwo z jakim traktują miejscowych, jednocześnie przyznawał jednak, że w trudnych dla parafii momentach, np. okresach głodu, bez ich pomocy placówka misyjna przestałaby istnieć ${ }^{67}$.

W roku 1938 ks. Franciszek Arciszewski objął pierwszą samodzielną parafię. Był to teren powiatu Żen-sien, który, z racji umiejscowienia tam kolei, miał strategiczne znaczenie dla okupanta. W czasie II wojny światowej (1939-1945) znacznie wzrosła pozycja polskiego misjonarza. Miejscowa ludność bardzo często zwracała się do niego $\mathrm{z}$ prośbą o pomoc i o radę 68 .

\footnotetext{
${ }^{64}$ Sylwetka duchowa, dz. cyt., s. 61.

${ }^{65}$ F. A r c i s z e w s k i, dz. cyt., s. 17-20.

66 Był to polski kapłan ks. Władysław Prinz (przyp. aut.); por. P. Kurtyka,

Ś. P. Brat Władystaw Prinz, ROZ, R. 40, 1937, nr 3-4, s. 251-256.

${ }^{67} \mathrm{~F}$. A r c i s z e w s k i, dz. cyt., s. 15-16.

68 Tamże, s. 21.
} 
Na początku lat 40. wieku XX misjonarz z Polski otrzymał pod swoją opiekę kolejną rolniczą wiejską parafię - Nankao. To tutaj, w roku 1944, w czasie ewangelizacji miejscowej ludności ks. Arciszewski po raz pierwszy spotkał bojówki komunistyczne ${ }^{69}$.

W wyniku wojny domowej anarchia w Chinach tylko się pogłębiła. Już wcześniej walczące $\mathrm{z}$ japońskim okupantem bojówki komunistyczne zajęły bez przeszkód północne prowincje kraju i utworzyły tzw. Rząd Pogranicza ${ }^{70}$. Prowadził on negocjacje z nacjonalistami za pośrednictwem Amerykanów ${ }^{71}$. Nie przyniosły one jednak większego efektu, gdyż ,czerwoni” nie przestrzegali rozejmu i zdobywali kolejne obszary Chin, korzystając z bierności wojsk Czang Kaj-szeka ${ }^{72}$.

W nocy z 14 na 15 sierpnia 1945 roku liczne odziały „bojówkarzy” Mao Zedonga przemaszerowały przez Nankao, terroryzując przy tym mieszkańców. Tak wydarzenia te zapamiętał proboszcz - ks. Franciszek Arciszewski: „W mojej wiosce zaroiło się od komunistycznych „żołnierzy”. Piszę ten wyraz w cudzysłowie, bo co to byli za żołnierze!? Bez umundurowania i bez broni. Każdy ubrany w to co kto miał, ten i ów nosił karabin, którym chyba jeszcze dziadek jego wojował i prawie zupełnie bez amunicji. Większość miała po parę zawieszonych u pasa granatów-chałupniczej produkcji i tyle. Przylazło to wszystko z zachodnich gór, gdzie komuniści mieli swoje bazy, gdyż Japończycy nie śmieli zapuszczać się $\mathrm{w}$ te niebezpieczne tereny. Czerwona masa przyszłaby zamanifestować swoją liczebną siłę"

Komuniści dążyli do utworzenia całkowicie zlaicyzowanego społeczeństwa, dlatego starali się za wszelką cenę usunąć z państwa wszystkich duchownych. Organizowano w tym celu specjalnie zaaranżowane widowiska skierowane przeciwko bogaczom oraz księżom, zwane „zemstą ludu”. Franciszek Arciszewski był świadkiem jednego z takich wydarzeń. W ciągu kilku godzin zamordowano wszystkie osoby zajmu-

\footnotetext{
69 Tamże, s. 12, 39.

${ }^{70}$ Rejon Pograniczny (przyp. aut.), por. Najnowsza historia Chin, red. G. W. A s t a fi ew, W. N. Niki forow, M. I. Sładkowskij, tłum. J. Urkowski, Warszawa 1976, s. 296-297; por. F. A r c i s z e w s k i, dz. cyt., s. 42.

71 F. Krzy ża k, In Nomine Domini. Nie nam lecz Imieniowi Twojemu Panie daj chwałe, cz. 2, http://adgentes.misjonarze.org/wp-content/uploads/2009/10/Chiny-Krzyzakcz2-final.pdf, [dostęp dnia 09.05.15], s. 11-12.

${ }^{72}$ Najnowsza historia Chin, dz. cyt., s. 315.

${ }^{73}$ F. A r c i s z e w s k i, dz. cyt., s. 40.
} 
jące reprezentacyjne stanowiska w Nankao. Ks. Arciszewski tak wspominał te „widowiska"74. „Na zebraniach zachęcano do rozrachunków, do pomszczenia się za doznane niegdyś krzywdy, poniżenia lub obelgi. I tu okazało się, że kobiety były bardziej zawzięte w szukaniu odwetu. Przy początkowej powściągliwości mężczyzn, kobiety pierwsze zaczęły wywlekać dawne, zdawałoby się już zapomniane urazy. Oskarżonymi zawsze byli ludzie znaczniejsi mieniem, wykształceniem albo pozycją społeczną. Z biegiem czasu bywało, że role się odwracały i poprzedni oskarżyciele stawali się oskarżonymi. Wreszcie nikt nie czuł się pewnym, nikt nikomu nie ufał. Zapanował terror""75.

Ks. Arciszewski swoje ocalenie podczas ,zemsty ludu” w Nankao tłumaczył lepszą sytuacją, w której znajdowali się zagraniczni misjonarze. Komuniści bali się mordować obcokrajowców, gdyż nie chcieli doprowadzić do całkowitej izolacji na arenie międzynarodowej swego państwa $^{76}$. Dodatkowo ich rządy były jeszcze nieugruntowane, a morderstwa cenionych i szanowanych przez społeczność zagranicznych duchownych z pewnością nie przysporzyłyby im popularności. Wielu parafian często występowało w obronie swoich kapłanów oraz wciąż starało się chodzić do kościoła i przyjmować sakramenty, za co bardzo często byli represjonowani, jak miało to miejsce w Nankao ${ }^{77}$.

Gdy komuniści rozprawili się z miejscową elitą, 5 września 1946 roku jako pierwszego księdza w wikariacie aresztowali ks. Franciszka Arciszewskiego. W następnym dniu odbył się sąd nad misjonarzem. Musiał on stanąć na niewielkiej scenie, a miejscowi zebrani poniżej, oskarżali go o najrozmaitsze przewiny: ,[...] Oskarżenia zaś były różne i nie pamiętam wszystkich. Najważniejsze były dwa. Jedno odnosiło się do sporu między chrześcijanami i poganami, jaki miał miejsce 52 lata temu. Historię tego zatargu znałem $\mathrm{z}$ opowiadań ${ }^{78}$. Drugie poważne oskarżenie, $[. .$.$] to że misja nie płaciła podatków ani państwowych, ani$

\footnotetext{
74 Tamże.

75 Tamże, s. 42.

${ }^{76}$ W. S o j k a, dz. cyt., s. 4.

${ }^{77}$ F. A r c i s z e w s k i, dz. cyt., s. 46-47.

${ }^{78}$ Gdy w Nankao powstała gmina chrześcijańska, zgłosiła ona pretensje do pagody, obok której rosły dwa cyprysy. Kiedy chrześcijanie wycieli drzewa, które były uznawane za święte przez pogan, powstał spór, prowadzący do rozlewu krwi. Ostatecznie załagodzono konflikt i w miejscu cyprysów postawiono kamienną stellę, por. F. A r c i s z e w s k i, dz. cyt., s. 53-54.
} 
lokalnych. Uderzyło mnie, że wszystkie skargi i zarzuty dotyczyły Kościoła, a nie było oskarżeń skierowanych przeciwko mnie osobiście. Byłem „winny” jako przedstawiciel tego Kościoła"79.

Odczytanie aktu oskarżenia przeciw polskiemu duchownemu musiano nagle przerwać, ponieważ rozpoczęła się ulewa. W następnym dniu do celi księdza Arciszewskiego przybyło kilku przedstawicieli komunistycznych nalegając, aby przyznał się do wszystkich zarzutów, na co ten ostatecznie wyraził zgodę i po trzech dniach aresztu mógł opuścić celę. Komuniści zadowolili się pokwitowaniem, które wystawił ks. Franciszek Arciszewski, że katolicki biskup znajdzie sposób, aby zapłacić za wszelkie szkody, jakie wyrządzili polscy duchowni w miejscowości i uregulować zaległe podatki. 8 września 1946 ostatecznie zlikwidowano polską misję w Nankao, a ks. Arciszewski udał się do Shuntehfü ${ }^{80}$.

Siedziba prefektury apostolskiej w Shuntehfu również znalazła się w rękach komunistycznych bojówek - została ostatecznie zdobyta nocą z 23 na 24 września roku $1945^{81}$.

W centrali polskiej misji również pojawili się komuniści, a 4 grudnia 1946 roku wszyscy przebywający w mieście polscy księża oraz siostry szarytki zostali uwięzieni wraz z chińskim personelem przytułku dla sierot i szpitala ${ }^{82}$. Aresztowano również biskupa Ignacego Krauze oraz ks. Franciszka Arciszewskiego, który po opuszczeniu Nankao dotarł już do prefektury ${ }^{83}$. Losu aresztowanych uniknęli jedynie kapłani znajdujący się wówczas poza Shuntehfu, m.in. ks. doktor Wacław Szuniewicz oraz ks. Franciszek Krzyżak ${ }^{84}$. Zgodnie z poleceniem biskupa udali się oni do Pekinu, by tam oczekiwać dalszego rozwoju sytuacji w prowincji Hopeh.

Oskarżyciele również nie potrafili wykazać żadnych poważnych uchybień w działalności placówki, a zarzuty stawiano samej instytucji, a nie poszczególnym kapłanom. W czasie przesłuchań komuniści posuwali się nawet do stosowania tortur wobec nich ${ }^{85}:,[\ldots]$ Byli oni bici i katowani. Najczęściej stosowaną torturą było wieszanie za

\footnotetext{
79 Tamże, s. 54.

${ }^{80}$ Tamże, s. 60-63.

${ }^{81}$ W. S o j k a, dz. cyt., s. 4.

${ }^{82}$ W. S o j k a, dz. cyt., s. 4.

${ }^{83}$ Tamże, s. 20-21.

${ }^{84}$ F. K r z y ż a k, dz. cyt., s. 8 .

${ }^{85}$ W. S o j k a, dz. cyt., s. 23.
} 
zawiązane od tyłu ręce. Ból wykręcanych stawów doprowadzał do utraty przytomności. Omdlałych spuszczano, oblewano wodą, by przywrócić ich do przytomności i znów dźwigano w górę [...]"86.

Pokazowy proces polskich misjonarzy odbył się w Shuntehfu 21 grudnia 1946 roku. Oprócz typowego sądu ludu na polskich kapłanów czekał również marsz ulicami miasta: „Powiązano nas dwójkami. Biskupowi nałożono wysoką papierową czapkę z szyderczymi napisami i umieszczono go w pierwszym szeregu. Ruszyliśmy w ulice miasta, otoczeni żołnierzami z bronią w ręku. Na czele pochodu szła grupa aktywistów. Po obu stronach ulic stali ludzie, najwidoczniej zawczasu rozmieszczeni na szlaku naszego pochodu. Miała to być nasza Droga Krzyżowa, szlak naszego poniżenia i pokaz nienawiści ludu do nas. Grupa na czele pochodu wykrzykiwała hasła przeciwko nam, wznosząc zaciśnięte pięści, a widzowie mieli powtarzać te okrzyki i nienawistny gest" ${ }^{\prime 87}$.

Misjonarze zostali oskarżeni m.in. o szpiegostwo, za które groziła kara śmierci. Pomimo ciężaru zarzutów zostali oni stosunkowo szybko zwolnieni z więzienia ${ }^{88}$.

Według ks. Arciszewskiego podstawowym problemem chińskiego „,wymiaru sprawiedliwości” był fakt, iż misjonarze i szarytki oddawali miejscowym nieocenione przysługi. Chodziło tu zwłaszcza o darmową opiekę zdrowotną, która wcześniej na tym obszarze nie istniała, ale też o np. upowszechnienie szkolnictwa podstawowego, czy nawet nowych metod uprawy roli. Śledczy musieli posuwać się do absurdalnych pomówień o niemoralne praktyki czy brak zachowywania czystości przez księży. Takie praktyki rodziły opór Chińczyków, którzy wiedzieli, że są to kłamstwa. Ostatecznie komuniści skrócili kary więzienia dla misjonarzy i zakonnic, zadowalając się ich wygnaniem ${ }^{89}$.

Pierwsi kapłani i szarytki z Polski opuścili więzienie już w styczniu 1947 roku. Wszyscy ocaleni powrócili do zrujnowanej misji, zdawali sobie jednak sprawę $\mathrm{z}$ faktu, że ich pobyt w placówce to jedynie stan przejściowy. Jesienią roku 1947 komuniści nakazali wszystkim cudzoziemcom opuszczenie prowincji Hopeh ${ }^{90}$. Nasilały się represje

\footnotetext{
${ }^{86}$ F. A r c i s z e w s k i, dz. cyt., s. 67.

87 Tamże, s. 70.

${ }^{88}$ S. R o s p o n d, Polscy Misjonarze, dz. cyt.

${ }^{89}$ S. R o s p o n d, Polscy Misjonarze, dz. cyt.

${ }^{90}$ F. A r c i s z e w s k i, dz. cyt., s. 84.
} 
i prześladowania zarówno wobec kapłanów, jak i ich wiernych, dlatego biskup Krauze zdecydował o ewakuacji całej prowincji.

Podróż do stolicy Chin, skąd amerykańskie samoloty wywoziły cudzoziemców, była niezwykle trudna i długa. Po drodze zdarzały się nieprzewidziane postoje wymuszane przez działania wojenne.

W czasie wielomiesięcznej podróży do Pekinu ks. Franciszek Arciszewski został aresztowany i na prawie pół roku uwieziony w mieście Szymen $^{91}$. Ostatecznie dopiero 1 lipca roku 1948 dotarł on do oblężonego przez komunistów Pekinu ${ }^{92}$. Gdy miasto zostało zajęte przez wojska Mao Zedonga, polscy księża udali się do Szanghaju, skąd postanowiono rozesłać ich do innych domów zgromadzenia. Właśnie tutaj ks. Franciszek Arciszewski otrzymał list z Kurii Generalnej Zgromadzenia. Wiele lat później, w 1990 roku, tak wspominał ten dzień: „Już w Szanghaju otrzymałem nominacje na superiora domu w Shuntehfu. Dokument nosił datę 15 listopada 1948 roku. Risum tenere, amici!!! - przecież dom zgromadzenia w Shuntehfu już dawno przestał istnieć! Więcej niż rok temu wyjechali stamtąd ostatni konfratrzy. Większość wspólnoty rozproszyła się już była po różnych kontynentach, ale w Paryżu, gdzie wtedy urzędowała Kuria Generalna Zgromadzenia, jakby nie wiedziano o tym. Chociaż samo to, że nominacje przesłano mi do Szangchaju [sic!], (nawet nie do Pekinu) też swoje mówi. A może Kuria Generalna Zgromadzenia zapragnęła naśladować Stolicę Apostolską, która mianuje biskupów «in partibus infidelium» i dlatego mianowano mnie «superiorem in partibus infidelium»... albo inaczej mówiąc: superiorem tytularnym. Wyróżnienie nie lada!"93.

W tym samym czasie wioski chińskie były już całkowicie zajęte przez komunistów, a słabnący opór stawiano jedynie w miastach, w których wciąż broniły się pozostałości dawnych chińskich wojsk pomocniczych. Formacje to były systematycznie likwidowane przez czerwone bojówki, które zdobywały w ten sposób bardzo potrzebną broń i amunicję. Klęska wojsk Czang-Kaj-Szeka i ich ucieczka na Tajwan doprowadziła do ostatecznego wyrugowania zagranicznych

\footnotetext{
91 W. S o j k a, Koniec misji w Chinach, mps, b.m. 1986, s. 23.

92 S. R o s p o n d, Polscy Misjonarze św. Wincentego a Paulo w Chinach (1929-1949), dz. cyt.

${ }^{93}$ F. A r c is z e w s k i, dz. cyt., s. 108.
} 
misjonarzy z Chin. Zwycięzcy komuniści rozpoczęli budowę ateistycznego społeczeństwa.

Spośród czterdziestu polskich misjonarzy przebywających w Chinach, trzech straciło życie na powierzonych im placówkach. Pierwszym $\mathrm{z}$ nich był brat Władysław Prinz ${ }^{94}$. Został on zamordowany przez japońskie wojska inwazyjne w roku 1937. Ks. Franciszek Arciszewski w swoich wspomnieniach zanotował, że męczeńską śmierć w płomieniach ponieśli wówczas jeszcze inni kapłani wraz z katolickim biskupem miejsca ${ }^{95}$. W roku 1939 na zapalenie opon mózgowych zmarł ks. Antoni Górski ${ }^{96}$. Natomiast w roku 1943 wskutek powikłań pogrypowych ks. Wacław Jęczmionka - autor pierwszych opracowań historii polskiej misji w Chinach ${ }^{97}$.

Tragiczny los spotkał również księdza Kazimierza Całkę, który w przededniu drugiej wojny światowej powrócił do kraju, by przeprowadzać zbiórki na rzecz misji w Shuntehfu. Po wkroczeniu Niemców do Polski został aresztowany i osadzony w obozie koncentracyjnym. Zmarł w Dachau w roku $1942^{98}$.

Ostatni wygnańcy z Shuntehfu dotarli do Pekinu jesienią roku 1948, kiedy los katolickich misji był już ostatecznie przesądzony ${ }^{99}$. Kapłanom nie pozostawiono żadnego wyboru i wszyscy bez wyjątku musieli opuścić Chiny pod groźbą ponownego aresztowania i egzekucji. Większość misjonarzy wyjechała do USA oraz Australii i na Filipiny, aby nadal pracować jako duszpasterze, tylko niektórzy z nich zdecydowali się na powrót do Polski ${ }^{100}$.

Franciszek Arciszewski w dniu 3 lutego 1949 roku wsiadł na pokład okrętu Generał Gordon, którym udał się do Stanów Zjednoczonych $^{101}$. Na miejscu dowiedział się, że liczna Polonia w Australii jest praktycznie zupełnie pozbawiona opieki duszpasterskiej, o którą usilnie zabiega. Jeszcze w tym samym roku ks. Arciszewski opuścił ame-

\footnotetext{
94 Por. przyp. 66.

${ }^{95}$ F. A r c i s z e w s k i, dz. cyt., s. 12.

$96 \mathrm{~S}$. R o s p o n d, Biogramy polskich misjonarzy, dz. cyt.

97 Tamże.

98 Tamże.

99 S. R o s p o n d, Polscy Misjonarze, dz. cyt.

100 Tamże.

101 Sylwetka duchowa, dz. cyt., s. 126-128.
} 
rykańskie Derby i popłynął do Australii ${ }^{102}$. Na miejscu rozpoczął posługę w Sydney i okolicznych obozach dla uchodźców z Polski ${ }^{103}$.

W krótkim czasie do Australii przybyło czterech dawnych misjonarzy z Chin - księża: Trzeciak, Cymbrowski, Czapla oraz Sojka ${ }^{104}$. Pracowali oni ponownie w trudnych warunkach zarówno klimatycznych, jak i lokalowych. Zostali rozlokowani na dużym obszarze wokół metropolii. Ks. Arciszewski w swojej pracy miał do pomocy Wojciecha Sojkę, z którym mieszkał przy kościele św. Wincentego w Ashfield ${ }^{105}$.

Ks. Franciszek Arciszewski pełnił funkcję proboszcza parafii w Sydney. W czasie swojego pobytu w Australii starał się również zaktywizować tamtejszą Polonię. Doprowadził do powstania m.in. ośrodka opiekuńczego dla polskich dzieci prowadzonego przez siostry nazaretanki w roku 1956 oraz przyczynił się do zainicjowania budowy kościoła dla Polaków w miejscowości Marayong ${ }^{106}$.

Miejscowi hierarchowie $\mathrm{z}$ czasem stracili zainteresowanie utrzymywaniem polskich misjonarzy. Uniemożliwiono im budowę własnego domu, odmowę tłumacząc tym, iż już istnieją lokalne struktury księży misjonarzy ${ }^{107}$. W tej sytuacji członkowie Zgromadzenia Misji w większości wyjechali do USA.

Ks. Franciszek Arciszewski opuścił ostatecznie Sydney w roku 1961. Wcześniej przez kilka miesięcy przebywał w Krakowie, przygotowując się do kolejnej zmiany miejsca posługi duszpasterskiej ${ }^{108}$. Po raz drugi przybył do Ameryki Północnej w styczniu 1962 roku, gdzie został przydzielony do pracy w domu misyjnym Whitestone w Nowym Jorku ${ }^{109}$. Przebywał tam przez trzy lata, pracując jako duszpasterz okolicznych mieszkańców. Przez cały czas utrzymywał stały kontakt korespondencyjny ze swoimi siostrami mieszkającymi w Polsce oraz ich dziećmi. Pomimo cenzury otrzymywał od nich informacje o sytuacji w ojczyźnie. Jak

\footnotetext{
102 AMS, AP Arciszewskiego, sygn. I/1, Życiorys ks. Arciszewskiego z roku 1967.

${ }^{103}$ W. S o j k a, Pamiętnik, USA 1967, rkps, [b.n.].

104 Tamże.

105 Tamże.

${ }^{106}$ M. Kałuski, Polish religious life in Australia, „Studia Polonijne”, t. 12, 1989, s. 184.

${ }^{107}$ W. S o j k a, dz. cyt.

108 AMS, AP Arciszewskiego, sygn. I/1, Kwestionariusz osobowy dla cudzoziemców składających podanie o zezwolenie na pobyt stały w Polskiej Rzeczypospolitej Ludowej z roku 1985.

109 AMS, AP Arciszewskiego, sygn. I/1, Życiorys ks. Arciszewskiego z roku 1967.
} 
wspominał po latach, już wtedy marzył o powrocie do Polski, ponieważ czuł się w Ameryce Północnej coraz bardziej wyobcowany.

W latach 1965-1973 był superiorem domu misyjnego w Utica, również znajdującego się w dystrykcie Nowy Jork ${ }^{110}$. W czasie swej posługi jako superior wystąpił w roku 1967 o zmianę obywatelstwa z polskiego na amerykańskie. Ks. Arciszewski uważał, że, pomimo jego pragnień, nie dane mu będzie powrócić na stałe do kraju przodków. Komunistyczne władze Polski Ludowej skutecznie utrudniały mu nawet krótkie wizyty. Zmiana obywatelstwa była również podyktowana sporymi ułatwieniami formalnymi jakie posiadali ludzie $\mathrm{z}$ amerykańskim paszportem. Jako superior potrzebował ich $\mathrm{w}$ swej pracy i posłudze. Procedurę przeszedł pozytywnie i od tej pory funkcjonował jako ks. Francis Arciszewski obywatel Stanów Zjednoczonych Ameryki Północnej ${ }^{111}$.

Po zakończeniu działalności superiora powrócił do Whitestone, gdzie pracował nadal jako duszpasterz aż do roku $1982^{112}$. Wówczas to przeniósł się do Ansonii do parafii św. Józefa. Pracował tam jako asystent do roku $1988^{113}$. W czasie swojego pobytu w Ansonii ponad siedemdziesięcioletni już kapłan zdecydował się na powrót do ojczyzny, ponieważ wydarzenia w Polsce zapowiadały koniec epoki komunizmu ${ }^{114}$. Tak pisał wówczas do wizytatora prowincji amerykańskiej: „Jak już oświadczyłem w rozmowie z księdzem wizytatorem, po dłuższym zastanowieniu zdecydowałem się wrócić do mojej prowincji pochodzenia, to jest Prowincji Polskiej. Porozumiałem się już $\mathrm{w}$ tej sprawie $\mathrm{z}$ księdzem wizytatorem [Władysławem] Bombą i otrzymałem gorące zaproszenie"115.

\footnotetext{
110 Tamże.

111 AMS, AP Arciszewskiego, sygn. I/1, Certificate of Naturalization.

112 AMS, AP Arciszewskiego, sygn. I/1, Kwestionariusz osobowy dla cudzoziemców składających podanie o zezwolenie na pobyt stały w Polskiej Rzeczypospolitej Ludowej $\mathrm{z}$ roku 1985.

113 AMS, AP Arciszewskiego, sygn. I/1, Kwestionariusz osobowy dla cudzoziemców składających podanie o zezwolenie na pobyt stały w Polskiej Rzeczypospolitej Ludowej $\mathrm{z}$ roku 1985.

${ }^{114}$ Kolejna fala strajków, m.in. w Gdańsku, w hucie im. Lenina w Krakowie. W ZSRS realizowano nadal program reform Gorbaczowa, tzw. pierestrojkę (przyp. aut.), por. AMS, AP Arciszewskiego, sygn. II/2, Listy ks. Arciszewskiego do wizytatora, Ansonia 1985-1986.

115 AMS, AP Arciszewskiego, sygn. II/2, List ks. Arciszewskiego do wizytatora, Ansonia, 4 XII 1986.
} 
Otrzymanie zaproszenia nie było takie łatwe, ponieważ od blisko dwudziestu lat ks. Arciszewski figurował w ewidencji jako obywatel Stanów Zjednoczonych. Nadzieje na spokojną starość w Polsce stały się realne dopiero pod koniec lat osiemdziesiątych XX wieku. Skompromitowana władza komunistyczna, po klęsce stanu wojennego w 1982 i całkowitym jego zniesieniu 22 lipca 1983 roku, coraz bardziej traciła zarówno wpływy na arenie międzynarodowej, jak i kontrolę nad społeczeństwem. Następowała też powolna odwilż w relacjach państwo Kościół, dlatego też ks. Arciszewski wystąpił o pozwolenie na osiedlenie się w kraju przodków. Swój wniosek o kartę stałego pobytu motywował w następujący sposób: „Kiedy przybyłem do Stanów Zjednoczonych, należałem do Polskiej Wice-Prowincji Zgromadzenia Księży Misjonarzy. Od owego czasu zaszły poważne zmiany w organizacji Zgromadzenia na terenie Stanów Zjednoczonych. Wice-prowincja polska przemieniona została na prowincję amerykańską. Młodszy personel prowincji nie jest zainteresowany sprawami polskimi. W moim wieku jest mi coraz trudniej zrozumieć i być zrozumianym przez środowisko, w którym żyję i pracuję. Spodziewam się, że łatwiej mi będzie zżyć się z ludźmi o wspólnym charakterze narodowym, o tej samej kulturze i tradycji. W moim wieku nie nadaję się do pełno-etatowej pracy, ale w ograniczonym zakresie mogę być jeszcze pożytecznym, według zdania i decyzji przełożonych Zgromadzenia. Materialne względy nie wchodzą w rachubę. Sentyment? - Może. Jesteśmy narodem sentymentalnym i z naszym sentymentalizmem musimy żyć"116.

Podanie księdza Arciszewskiego zostało rozpatrzone pozytywnie i po kilkumiesięcznym oczekiwaniu w roku 1987 otrzymał on pozwolenie na wjazd i osiedlenie się w Polsce ${ }^{117}$. Do ojczyzny powrócił ostatecznie w roku $1988^{118}$.

Początkowo planował zamieszkać w domu Zgromadzenia Księży Misjonarzy na Stradomiu, skąd wiele dziesiątek lat wcześniej wyruszył do Chin. Ostatecznie, w zgodzie $\mathrm{z}$ wolą przełożonych, osiadł w domu zgromadzenia przy bazylice św. Krzyża w Warszawie. W Polsce po-

\footnotetext{
116 AMS, AP Arciszewskiego, sygn. II/2, List ks. Arciszewskiego do wizytatora, Ansonia, 4 XII 1986.

117 AMS, AP Arciszewskiego, sygn. I/1, Pozwolenie wydane przez Konsulat Generalny Polskiej Rzeczypospolitej Ludowej w Nowym Jorku z 29.12.1987.

118 AMS, AP Arciszewskiego, sygn. I/1, Kwestionariusz wizowy z 23.12.1987.
} 
mimo zaawansowanego wieku przė̇ył jeszcze osiemnaście lat, będąc wciąż aktywnym kapłanem.

Ks. Franciszek Arciszewski, ostatni superior domu w Shuntehfu, zmarł w Warszawie 19 sierpnia 2006 roku, mając dziewięćdziesiąt

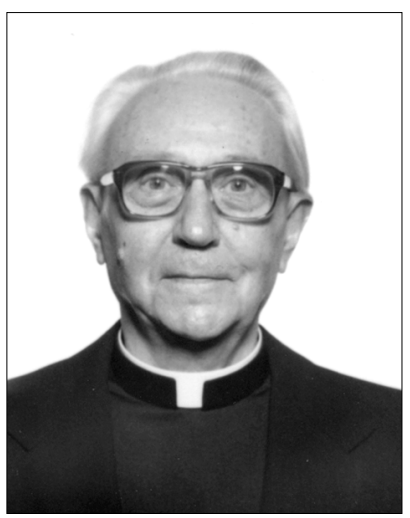
sześć lat ${ }^{119}$. Został pochowany z wielkimi honorami 24 sierpnia na warszawskim cmentarzu Powązkowskim $^{120}$.

Wspomnienia ks. Franciszka Arciszewskiego, które przywołano w tekście, powstawały długo. Pierwsze ślady i próby ich usystematyzowania pojawiły się już w latach 40. wieku XX. Ostatecznego kształtu nabrały w roku 1990. Są one ważne ze względu na szczegółowe przedstawienie w nich sytuacji duchownych w niespokojnych czasach. To również interesujące studium ukazujące spotkanie młodego człowieka z odmienną kulturą oraz z okrucieństwem wojny.

Przez blisko czterdzieści lat ks. Arciszewski korespondował z chińskimi przyjaciółmi, którym udało się uciec z kraju, a także zbierał materiały dotyczące Chin i chrześcijaństwa na tych terenach. Jak sam zauważył w jednym ze swoich listów, był w Chinach jedynie czternaście lat, jednak to właśnie z tym miejscem czuł się najbardziej związany ${ }^{121}$.

\section{Bibliografia}

\section{Źródła archiwalne}

Archiwum Polskiej Prowincji Zgromadzenia Księży Misjonarzy na Stradomiu

Akta personalne Franciszka Arciszewskiego, sygn. I/1, Akta personalne Franciszka Arciszewskiego, sygn. II/1, Korespondencja, Arciszewski F., Wspomnienia z Chin, mps, Warszawa 1990.

\footnotetext{
${ }^{119}$ AMS, AP Arciszewskiego, sygn. I/1, Akt zgonu z 21.08.2006.

${ }^{120}$ AMS, AP Arciszewskiego, sygn. I/1, Nekrolog.

121 AMS, AP Arciszewskiego, sygn. II/2, List ks. Arciszewskiego do ks. Vincentego Changa z 14.03.1993.
} 


\section{Źródła drukowane}

List X. Franciszka Stawarskiego do W. X. Jęczmionki w Chetmnie, Roczniki Obydwu Zgromadzeń, R. 35, 1932, nr 1, s. 35-44.

List X. Wacława Szuniewicza do jednej z Sióstr Miłosierdzia, Roczniki Obydwu Zgromadzeń, R. 35, 1932, nr 1, s. 29-30.

Sojka W., Koniec misji w Chinach, b.m. 1986.

Sylwetka duchowa księdza doktora Wactawa Szuniewicza, oprac. F. Stawarski, Brasil 1977.

\section{Opracowania}

Broda K., Zgromadzenie Księży Misjonarzy w Chinach, cz. 1 (szkic historyczny), „Meteor”, R. 23, 1931, nr 5, s. 117-122.

Broda K., Zgromadzenie Księży Misjonarzy $w$ Chinach, cz. 2: Pod sztandarem krzyża, „Meteor”, R. 23, 1931, nr 5, s. 123-125.

Fendzin S., Wrażenia z podróży I. grupy misyjnej XX. Misjonarzy do Chin w roku 1929, ROZ, R. 34, 1931, nr 2, s. 165-176.

Jęczmionka W., Prefektura Apostolska Shuntehfu Chiny 1935, cz. 1, $\mathrm{http} / /$ adgentes.misjonarze.org/wp-content/uploads/2009/10/Chiny-Jeczmion ka-cz1-final.pdf, [dostęp dnia 09.05.15].

Kałuski M., Polish religious life in Australia, „Studia Polonijne”, t. 12, 1989, s. 179-197.

Krótka wiadomość o duchu i celach Zgromadzenia XX. Misjonarzy, „Roczniki Obydwu Zgromadzeń św. Wincentego a Paulo", R. 35,1932, nr 1, s. 6-7.

Krzyżak F., In Nomine Domini. Nie nam lecz Imieniowi Twojemu Panie daj chwate, cz. 1-2, http://adgentes.misjonarze.org/wp-content/uploads/2009/10/ Chiny-Krzyzak-cz2-final.pdf, [dostęp dnia 09.05.15].

Kurtyka P., S. P. Brat Władystaw Prinz, „Roczniki Obydwu Zgromadzeń”, R. 40, 1937, nr 3-4, s. 251-256.

Mezzadri L., Onnis F., Historia Zgromadzenia Misji, t. II/1: Zgromadzenie Misji w XVIII w.: Francja, Włochy, Misje (1697-1788), thum. W. Bomba, Kraków 2002.

Misjonarze św. Wincentego a Paulo w Polsce (1651-2001), t. I: Dzieje, red. S. Rospond, Kraków 2001.

Misjonarze św. Wincentego a Paulo w Polsce (1651-2001), t. II-1: Biografie, red. J. Dukała, Kraków 2001.

Najnowsza historia Chin, red. G.W. Astafiew, W. N. Nikiforow, M. I. Sładkowskij, thum. J. Urkowski, Warszawa 1976.

Rospond S., Polscy Misjonarze św. Wincentego a Paulo w Chinach (1929-1949), http://famvin.org/Wiki-pl/Polscy_Misjonarze_\%C5\%9Bw._Wincentego_a_Pau lo_w_Chinach_\%281929_-_1949\%29, [dostęp dnia 09.05.15].

Wielawski J., Polska Misja katolicka w Chinach, „Roczniki Obydwu Zgromadzeń”, R. 37, 1934, nr 4, s. 377-379. 
JOANNA BRZEGOWY

\title{
Z RUDOMINA DO SHUNTEHFU. ŻYCIE MISYJNE WE WSPOMNIENIACH KS. FRANCISZKA ARCISZEWSKIEGO CM (1910-2006) - PRZYCZYNEK DO DZIEJÓW PREFEKTURY APOSTOLSKIEJ ZGROMADZENIA MISJI W PÓŁNOCNYCH CHINACH
}

Streszczenie: Ks. Franciszek Arciszewski CM, misjonarz w Chinach, Australii i Stanach Zjednoczonych pozostawił po sobie bogatą spuściznę w postaci dokumentów, notatek własnych, listów oraz wspomnień i fotografii, związanych również z pracą w Chinach, przechowywanych obecnie w Archiwum Polskiej Prowincji Księży Misjonarzy na Stradomiu. Ks. Arciszewski przebywał w Chinach zaledwie czternaście lat, jednak był to okres nieustannych walk, zarówno z wrogiem zewnętrznym - Japonią, jak i wewnętrznych tarć na linii nacjonaliści - komuniści. Ze wspomnień ks. Arciszewskiego, spisanych w roku 1990, a więc przeszło pięćdziesiąt lat po wspominanych wydarzeniach, wyłania się obraz kraju ogarniętego wojenną zawieruchą, gdzie najbardziej pokrzywdzonymi okazują się być zwykli ludzie, z którymi na co dzień przebywali i wśród których mieszkali księża misjonarze.

Słowa kluczowe: Ashfield, Hopeh, Marayong, misje chińskie, Shuntehfu, Utica, ks. Wacław Szuniewicz, Zgromadzenie Księży Misjonarzy św. Wincentego a Paulo.

\section{FROM RUDOMIN TO SHUNTEHFU. MISSIONARY LIFE IN THE MEMOIRS OF FATHER FRANCISZEK ARCISZEWSKI CM (1910-2006) - A CONTRIBUTION TO THE HISTORY OF THE APOSTOLIC PREFECTURE OF THE CONGREGATION OF THE MISSION IN NORTHERN CHINA}

\begin{abstract}
Fr. Franciszek Arciszewski CM, a missionary in China, Australia and the United States left a rich legacy in the form of documents, notes, letters and memoirs as well as photographs, also those related to his work in China and currently kept in the Archives of the Polish Province of the Congregation of the Mission on Stradom street, Krakow. Fr. Arciszewski stayed in China for only fourteen years, however, it was a period of constant fighting with an external enemy - Japan as well as internal friction between nationalists and communists. From the memoirs of Father Arciszewski, written in 1990 - more than fifty years after the above mentioned events, a picture emerges of a country affected by war turmoil, where most of the victims turn out to be ordinary people, with whom missionaries stayed and lived on a daily basis.
\end{abstract}

Keywords: Hopeh, Shuntehfu, Ashfield, Marayong, Utica, Congregation of the Mission, Chinese missions, Apostolic Prefecture in Shuntehfu. 